\title{
PENGARUH KEPEMIMPINAN, MOTIVASI KERJA DAN PELATIHAN TERHADAP KINERJA PEGAWAI NEGERI SIPIL DI DINAS PEKERJAAN UMUM DAN PENATAAN RUANG KABUPATEN TAPANULI TENGAH
}

\author{
Ferdinan Sihaloho*1) \\ ${ }^{1)}$ Program Pasca Sarjana, Unversitas Terbuka \\ *Penulis Korespondensi: ferdi250609@gmail.com
}

\begin{abstract}
Abstrak
Kinerja dapat diartikan hasil kerja secara kualitas dan kuantitas yang dicapai oleh seorang pegawai dalam melaksanakan tugasnya sesuai dengan tanggung jawab yang diberikan kepadanya. Tujuan penelitian ini adalah untuk mengetahui dan menganalisis pengaruh kepemimpinan, motivasi kerja dan pelatihan secara bersama-sama terhadap kinerja pegawai Dinas Pekerjaan Umum dan Penataan Ruang Kabupaten Tapanuli Tengah. Jumlah populasi dan sampel sebanyak 52 orang. Data dikumpulkan menggunakan kuesioner dan wawancara. Kuesioner terlebih dahulu diuji validitas dan reliabilitasnya. Metode analisis data dalam penelitian ini menggunakan analisis regresi berganda. Berdasarkan hasil penelitian diketahui kepemimpinan, motivasi kerja dan pelatihan secara bersama-sama (serempak) berpengaruh positif dan signifikan terhadap kinerja pegawai negeri sipil pada Dinas Pekerjaan Umum dan Penataan Ruang Kabupaten Tapanuli Tengah. Pimpinan harus memperbanyak mengirim peserta mengikuti pelatihan yang benar-benar dapat meningkatkan kemampuan kerja pegawai, sehingga akan berdampak pada peningkatan kinerja pegawai dan bermuara pada peningkatan kinerja instansi juga.
\end{abstract}

\section{Keywords: Kepemimpinan, Motivasi Kerja, Pelatihan dan Kinerja}

Informasi Artikel:

Artikel Diterima: 18 Februari 2021

Artikel Direvisi: 28 Februari 2021

Artikel Disetujui: 14 Maret 2021 


\section{PENDAHULUAN}

Berbicara mengenai kinerja sangatlah penting, karena kinerja merupakan salah satu tolok ukur dari kualitas organisasi. Untuk meningkatkan kinerja pegawai merupakan salah satu strategi pembangunan untuk sebuah Negara dalam menjalankan proses kenegaraannya. Pada pelaksanaan tugasnya, pegawai bertindak sebagai unsur dari SDM yang mempunyai peranan menyelenggarakan tugas umum pemerintahan yang bertujuan untuk pembangunan nasional.

Salah satu pendekatan dalam upaya meningkatkan kinerja pegawai tersebut dapat dilakukan melalui praktek kepemimpinan. Kepemimpinan merupakan salah satu faktor untuk menentukan kinerja maupun tingkat produktif dari suatu instansi. Oleh karena itu, instansi yang bergerak dibidang pelayanan publik yang menginginkan tingkat kinerja pegawai diinstansinya, maka instansi tersebut dituntut untuk mengoptimalkan kinerja pegawainya. Salah satu pendekatan dalam upaya meningkatkan kinerja pegawai tersebut dapat dilakukan melalui praktek kepemimpinan. Pemimpin haruslah menjadi role model di dalam organisasi untuk mencapai visi dan misi instansi. Seperti dalam konsep exemplary leadership yang digagas James dan Barry (2015) yang menyebutkan bahwa model The Way atau memimpin dengan memberi contoh/teladan merupakan perilaku yang sangat penting ditunjukkan oleh pemimpin. Sebuah studi yang dilakukan oleh Yeh dan Hong (2012) menyebutkan dalam kegiatan kepemimpinan, motivasi dapat dikatakan suatu yang esensial dalam penerapan kepemimpinan, disebabkan pemimpin merupakan pemotivasi. Pullin, (2013) menyebutkan ada hubungan yang sangat erat antara kepemimpinan dengan motivasi, dikarenakan seseorang pemimpin akan berhasil, jika mampu menggerakkan bawahannya untuk meraih yang sudah ditetapkan serta pemimpin harus mampu memotivasinya.

Pemimpin akan bekerja bersama-sama dengan bawahannya oleh karena itu dibutuhkan kemampuan memotivasi bawahan supaya lebih giat bekerja. Kesuksesan seorang pegawai dalam bekerja atau mempunyai kinerja yang tinggi dapat dipengaruhi dalam diri maupun dari luar pegawai tersebut. Seseorang pegawai mempunyai kemampuan spesifik dan profesional tetapi belum tentu dapat bekerja dengan baik atau berkinerja lebih tinggi. Untuk itu perlu diberikan motivasi kerja, dimana dorongan yang ada di dalam diri seseorang pegawai dapat membangkitkan, mengarahkan dan menjaga supaya bekerja lebih giat dan antusias untuk mencapai tujuan organisasi. Di dalam diri pegawai yang termotivasi memiliki sifat pantang menyerah dalam melaksanakan pekerjaannya atau didalam diri pegawai tersebut ada efikasi diri. Pegawai yang termotivasi biasanya akan berusaha untuk menunjukkan bahwa dirinya mampu menyelesaikan seluruh pekerjaannya. Semangat yang ditunjukkan tidak serta merta untuk mendapatkab apa yang diinginkan, tetapi ada suatu dorongan dari dalam dirinya untuk mencapainya. Ada sebuah ungkapan yang menyatakan bahwa the man behind of the gun yang memiliki arti secanggih-canggihnya 
senjata yang dimiliki, tetapi jika tidak ada seseorang yang mampu menggunakan, semuanya tidak berguna. Hal ini mengindikasikan bahwa manusia merupakan salah satu sumber daya yang penting di dalam organisasi.

Sadar akan kemampuan kerja atau keterampilan merupakan kunci sesorang pegawai dapat berkinerja tinggi, maka pemimpin berusaha meningkatkan kapabilitas pegawainya dengan melaksanakan kegiatan pelatihan. Tujuan pelatihan yang dilakukan oleh perusahaan adalah untuk meningkatkan produktivitas, meningkatkan kualitas, mendukung perencanaan SDM, meningkatkan moral anggota, memberikan kompensasi yang tidak langsung, meningkatkan kesehatan dan keselamatan kerja, mencegah kedaluarsa kemampuan dan pengetahuan personel, meningkatkan perkembangan kemampuan dan keahlian personel (Widodo, 2015:84).

Dinas Pekerjaan Umum dan Penataan Ruang Kabupaten Tapanuli Tengah merupakan Operasi Perangkat Daerah (OPD) yang berhubungan langsung dengan penyedia jasa (kontraktor) sebagai pelaksana konstruksi. Sebelum pelaksanaan konstruksi dilakukan, Dinas Pekerjaan Umum dan Penataan Ruang Kabupaten Tapanuli Tengah melaksanakan perencanaan teknis terlebih dahulu. Perencanaa teknis dilakukan secara swakelola oleh Dinas Pekerjaan Umum dan Penataan Ruang Kabupaten Tapanuli Tengah, yang mana jumlah pegawai yang terlibat dalam perencanaan relatif sama setiap tahunnya. Pegawai Negeri Sipil di lingkungan Dinas Pekerjaan Umum dan
Penataan Ruang Kabupaten Tapanuli Tengah berjumlah 53 (lima puluh tiga) orang, terdapat 12 orang yang telah mengikuti program pelatihan sehingga belum menunjukkan hasil yang memuaskan. Penyelesaian pekerjaan perencanaan teknis mengalami penurunan dengan bertambahnya waktu yang dibutuhkan untuk menyelesaikan pekerjaan tersebut yang pada akhirnya akan berdampak kepada waktu penyelesaian pelaksanaan fisik konstruksi dan pekerjaan terkait lainnya tidak sesuai jadwal.

\section{TINJAUAN PUSTAKA}

Kinerja merupakan perilaku nyata yang ditampilkan setiap orang sebagai prestasi kerja yang dihasilkan oleh pegawai sesuai dengan perannya dalam organisasi. Mangkunegara (2016:67) bahwa kinerja berasal dari kata job performance atau actual permormanse (prestasi kerja atau prestasi sesungguhnya yang dicapai seseorang). Selanjutnya Mangkunegara (2016:67) mendefinisikan kinerja adalah hasil kerja secara kualitas dan kuantitas yang dicapai oleh seorang pegawai dalam melaksanakan tugasnya sesuai dengan tanggung jawab yang diberikan kepadanya. Mulyadi (2015:63) mengartikan kinerja sebagai hasil kerja yang dicapai oleh pekerja atau pegawai secara kualitas dan kuantitas yang sesuai dengan tugas dan tanggungjawab mereka. Selanjutnya Priansa (2014:270) menyebutkan kinerja merupakan hasil yang diproduksi oleh fungsi pekerjaan tertentu atau kegiatan-kegiatan pada pekerjaan tertentu selama periode waktu tertentu. Berdasarkan beberapa pengertian diatas dapat disimpulkan bahwa kinerja 
pegawai merupakan prestasi atau hasil kerja yang diperoleh organisasi secara kualitas dan kuantitas yang dipengaruhi oleh beberapa faktor untuk mencapai tujuan organisasi.

Kepemimpinan adalah proses oleh seseorang atau kelompok mencoba untuk memengaruhi tugas-tugas dan sikap orang lain terhadap sebuah akhir yang dikehendaki untuk mencapai visi dan misi organisasi (Moeheriono 2014:382). Kepemimpinan merupakan aktivitas seseorang untuk memengaruhi individu, kelompok, dan organisasi sebagai satu kesatuan, sehingga kepemimpinan diberi makna sebagai kemampuan memengaruhi semua anggota kelompok dan organisasi agar bersedia melakukan kegiatan untuk mencapai tujuan kelompok dan organisasi (Situmeang 2016:72). Berdasarkan beberapa pengertian diatas dapat disimpulkan bahwa kepemimpinan merupakan kemampuan seseorang untuk dapat memengaruhi setiap anggota organisasi untuk melakukan visi dan misi untuk mencapai tujuan instansi baik secara efisen dan efektik.

Motivasi adalah daya dorong yang datang dari seseorang yang mengarahkan perilaku untuk mencapai suatu tujuan, dari perspektif manajemen, motivasi adalah usaha sadar untuk memengaruhi perilaku seseorang agar supaya mengarah tercapainya tujuan organisasi (Darodjat, 2015:187). Sedangkan Mangkunegara (2016:93) mendefinisikan motif merupakan suatu dorongan kebutuhan dalam diri pegawai yang perlu dipenuhi agar pegawai tersebut dapat menyesuaikan diri terhadap lingkungannya, sedangkan motivasi adalah kondisi yang menggerakkan pegawai agar mampu mencapai tujuan dan motifnya. Selanjutnya Mulyadi (2015:89) menyebutkan bahwa motivasi adalah dorongan baik dari orang lain maupun dari diri sendiri untuk mengerjakan suatu pekerjaan dengan sadar dan semangat untuk mencapai target tertentu. Berdasarkan beberapa pengertian diatas dapat disimpulkan bahwa motivasi kerja adalah sebuah dorongan yang ada didalam diri manusia yang dapat membangkitkan, mengarahkan dan menjaga supaya dapat bekerja lebih giat dan antusias untuk mencapai tujuan organisasi.

Hasibuan (2013:70) mendefinisikan pelatihan adalah suatu proses pendidikan jangka pendek dengan menggunakan prosedur yang sistematis dan terorganisir, sehingga pegawai operasional belajar pengetahuan teknik pengerjaan dan keahlian tujuan tertentu. Pelatihan adalah proses dimana pekerja mempelajari keterampilan, sikap dan prilaku yang diperlukan guna melaksanakan pekerjaan mereka secara efektif (Yulk, 2015:281). Berdasarkan beberapa pengertian diatas dapat disimpulkan bahwa pelatihan adalah sarana untuk mengembangkan sumber daya manusia yang berkerja pada organisasi yang berpengaruh terhadap produktivitas kerja dan efisiensi dalam bekerja baik untuk sumber daya manusia tersebut maupun organisasi.

\section{METODE PENELITIAN}

Penelitian ini adalah penelitian kausal untuk mengetahui hubungan dan pengaruh antar variabel independen dan variabel dependen. Desain kausal berguna untuk menganalisis bagaimana suatu variabel memengaruhi 
variabel lain dan berguna untuk penelitian yang bersifat eksperimen, dimana variabel independennya dilakukan secara terkendali oleh peneliti untuk melihat dampaknya secara langsung terhadap variabel dependennya (Umar 2008:13). Instrumen penelitian yang digunakan adalah kuesioner. Prosedur pengambilan data primer dan sekunder dengan cara observasi wawancara, dokumentasi. Populasi dalam penelitian ini yaitu seluruh pegawai yang berstatus Pegawai Negeri Sipil pada Dinas Pekerjaan Umum dan Penataan Ruang Kabupaten Tapanuli Tengah sebanyak 52 orang. Dalam penelitian ini teknik penentuan sampel yang digunakan adalah sampling jenuh. Sampling jenuh adalah teknik penentuan sampel bila semua anggota populasi digunakan sebagai sampel, atau penelitian yang ingin membuat generalisasi dengan kesalahan yang sangat kecil. Istilah lain sampel jenuh adalah sensus, dimana anggota populasi dijadikan sampel. Sugiyono, (2013:114). Besarnya sampel pada penelitian ini berjumlah 52 responden. Penelitian ini menggunakan populasi sama dengan sampel atau penelitian populasi.

Uji asumsi klasik yang digunakan dalam penelitian ini adalah uji normalitas, uji heteroskedastisitas, dan uji multikolinearitas. Setelah lolos uji asumsi klasik dilanjutkan dengan uji regresi linier berganda dan uji hipotesis, seperti analisis koefisien determinasi, uji signifikasi simultan (uji statistik F) dan uji signifikasi pengaruh parsial (uji t).

\section{HASIL DAN PEMBAHASAN}

\section{Hasil}

a. Hasil Pengujian Asumsi Klasik

1) Uji normalitas data

Nilai uji Kolmogorov Smirnor sebesar 0,875 dan signifikan 0,428 > 0,05 hal ini memberi arti data residual berdistribusi normal atau sudah memenuhi asumsi normalitas.

2) Uji multikolinieritas

Nilai tolerance variabel kepemimpinan sebesar 0,603 dan nilai Variance Inflation Factor (VIF) sebesar 1,659. Nilai tolerance variabel motivasi kerja sebesar 0,677 dan nilai Variance Inflation Factor (VIF) sebesar 1,476. Nilai tolerance variabel pelatihan sebesar 0,673 dan nilai Variance Inflation Factor (VIF) sebesar 1,486 dengan demikian dapat disimpulkan pada model regeresi terbebas dari asumsi multikolinearitas.

3) Uji heteroskedastisitas

Nilai signifikansivariabel kepemimpinan 0,079, variabel motivasi kerja 0,689 dan pelatihan 0,515 . Sehingga dapat disimpulkan model regresi tidak mengandung adanya heteroskedastisitas.

b. Hasil Pengujian Hipotesis

1) Hasil uji koefisien determinasi $\left(R^{2}\right)$

Tabel 1. Hasil Uji Koefisien Determinasi $\left(\mathrm{R}^{2}\right)$

\begin{tabular}{|c|c|c|c|c|}
\hline Model & $\mathrm{R}$ & $\mathrm{R}$ Square & $\begin{array}{c}\text { Adjusted R } \\
\text { Square }\end{array}$ & $\begin{array}{c}\text { Std. Error of } \\
\text { the Estimate }\end{array}$ \\
\hline 1 & $0,788^{\mathrm{a}}$ & 0,621 & 0,598 & 5,970 \\
\hline
\end{tabular}

Sumber : Hasil Penelitian 2019 (Data Diolah) $\mathrm{R}$ Square diketahui sebesar 0,621 atau 62,1 $\%$ variabel kinerja dapat dipengaruhi oleh variabel variabel kepemimpinan, motivasi kerja dan pelatihan. Sedangkan sisanya 37,9 
\% dapat dijelaskan oleh variabel-variabel lain yang tidak diteliti dalam penelitian ini.

2) Hasil pengujian serempak (Uji-F)

Tabel 2. Hasil Pengujian Serempak (Uji F)

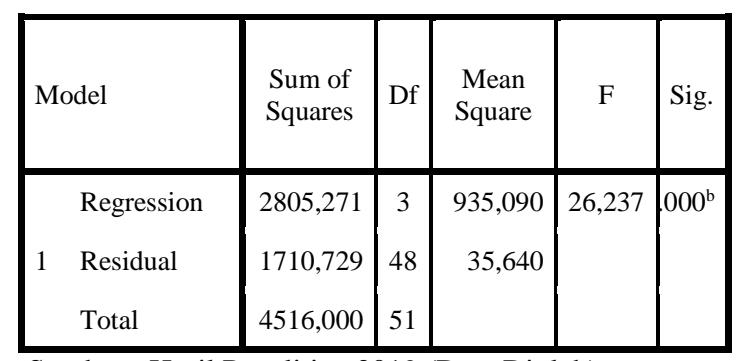

Sumber : Hasil Penelitian 2019 (Data Diolah)

Nilai $F_{\text {hitung }}$ sebesar 26,237 dan nilai $F_{\text {tabel }}$

sebesar 2,79, sehingga ditarik kesimpulan

$F_{\text {hitung }}>F_{\text {tabel }}(26,237>2,79)$, dan Sig.á $\left(0,000^{\mathrm{a}}\right)$ lebih kecil dari $\alpha 5 \%(0,005)$.

Dengan demikian kepemimpinan, motivasi kerja dan pelatiham secara bersama-sama (serempak) berpengaruh terhadap kinerja pegawai negeri sipil pada Dinas Pekerjaan Umum dan

Penataan Ruang Kabupaten Tapanuli Tengah

c. Hasil pengujian parsial (Uji $t$ )

Tabel 3. Hasil Pengujian Parsial (Uji $t$ )

\begin{tabular}{|c|c|c|c|c|c|}
\hline \multirow{2}{*}{ Model } & \multicolumn{2}{|c|}{$\begin{array}{l}\text { Unstandardized } \\
\text { Coefficients }\end{array}$} & \multirow{2}{*}{$\begin{array}{c}\begin{array}{c}\text { Standardized } \\
\text { Coefficients }\end{array} \\
\text { Beta }\end{array}$} & \multirow{2}{*}{$\mathrm{t}$} & \multirow{2}{*}{ Sig. } \\
\hline & B & $\begin{array}{l}\text { Std. } \\
\text { Error }\end{array}$ & & & \\
\hline \multirow{4}{*}{ Kepemimpinan } & 1,267 & 8,900 & & 0,142 & 0,887 \\
\hline & 0,318 & 0,119 & 0,307 & 2,684 & 0,010 \\
\hline & 0,383 & 0,108 & 0,384 & 3,560 & 0,001 \\
\hline & 0,292 & 0,118 & 0,268 & 2,474 & 0,017 \\
\hline
\end{tabular}

Sumber : Hasil Penelitian 2019 (Data Diolah)

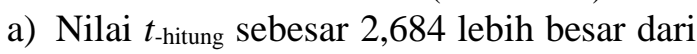

nilai $t_{\text {tabel }}$ sebesar 2,006 atau signifikan

(Sig-t) sebesar 0,010 lebih kecil dari $\alpha$

$(0,05)$ memberi arti secara parsial

variabel kepemimpinan berpengaruh positif dan signifikan terhadap kinerja pegawai.

b) Nilai $t_{\text {-hitung }}$ sebesar 3,560 yang lebih besar dari nilai $t_{\text {tabel }}$ sebesar 2,006 atau signifikan (Sig-t) sebesar 0,001 lebih kecil dari $\alpha(0,05)$. memberi arti secara parsial menjelaskan bahwa variabel motivasi kerja berpengaruh positif dan signifikan terhadap kinerja pegawai.

c) Nilai $t_{\text {hitung }}$ sebesar 2,474 yang lebih besar dari nilai $t_{\text {tabel }}$ sebesar 2,006 atau signifikan (Sig-t) sebesar 0,017 lebih kecil dari $\alpha(0,05)$ memberi arti secara parsial menjelaskan bahwa variabel pelatihan berpengaruh positif dan signifikan terhadap kinerja pegawai.

Berdasarkan Tabel 3 dapat diketahui persamaan regresi linier berganda yaitu : $\mathrm{Y}$ $=1,267+0,318 X_{1}+0,383 X_{2}+0,292 X_{3}+\varepsilon$. Dalam persamaa ini dapat dijelaskan sebagai berikut :

a) Nilai konstanta $(\alpha)$ sebesar 1,267 ini memberi arti bahwa apabila variabel kepemimpinan, motivasi kerja dan pelatihan dianggap konstan, maka tingkat variabel kinerja pegawai sebesar 1,267.

b) Nilai Koefisien regresi $\beta \mathrm{x}_{1}$ untuk variabel kepemimpinan bernilai positif sebesar 0,318 memberi arti bahwa pengaruh variabel kepemimpinan searah dan signifikan terhadap peningkatan kinerja pegawai. Dalam arti jika kepemimpinan yang diterapkan pada Dinas Pekerjaan Umum dan Penataan Ruang Kabupaten Tapanuli Tengah memiliki visi, sebagai pembimbing, berafiliatif, demokratis dan 
komunikatif, hal ini berdampak positif dan signifikan terhadap peningkatan kinerja pegawai negeri sipil di Dinas Pekerjaan Umum Dan Penataan Ruang Kabupaten Tapanuli Tengah.

c) Nilai koefisien regresi $\beta \mathrm{x}_{2}$ untuk variabel motivasi kerja bernilai positif 0,383 memberi arti bahwa pengaruh variabel motivasi kerja searah dan signifikan terhadap peningkatan kinerja pegawai. Dalam arti jika pegawai memiliki motivasi berprestasi dalam dirinya, maka akan berdampak positif dan signifikan terhadap peningkatan kinerja pegawai negeri sipil di Dinas Pekerjaan Umum dan Penataan Ruang Kabupaten Tapanuli Tengah.

d) Nilai Koefisien regresi $\beta \mathrm{x}_{3}$ untuk variabel pelatihan bernilai positif 0,292 memberi arti bahwa pengaruh variabel pelatihan searah dan signifikan dengan peningkatan kinerja pegawai. Dalam arti jika pelatihan yang dilaksanakan Dinas Pekerjaan Umum dan Penataan Ruang Kabupaten Tapanuli Tengah sering dilakukan dan sesuai dengan kebutuhan organisasi, maka akan berdampak positif dan signifikan terhadap peningkatan kinerja pegawai negeri sipil di Dinas Pekerjaan Umum dan Penataan Ruang Kabupaten Tapanuli Tengah.

\section{Pembahasan}

a. Pengaruh Kepemimpinan Terhadap Kinerja

Berdasarkan hasil pengujian hipotesis secara parsial diketahui bahwa kepemimpinan berpengaruh positif dan signifikan terhadap kinerja pegawai negeri sipil pada Dinas Pekerjaan Umum dan Penataan Ruang Kabupaten Tapanuli Tengah. Kualitas terpenting buat seorang pemimpin yaitu personal credibility sebagai fondasi kepemimpinan. Pentingnya sebuah personal credibility seorang pemimpin ini dapat terwujud dengan adanya kepercayaan di dalam organisasi, baik itu dari tim kepada pemimpin maupun sebaliknya, dan kepercayaan antar sesama anggota sesuai dengan ungkapan, "if people don't believe in the messenger, they won't believe the message". Hal ini sejalan dengan penelitian yang telah dilakukan oleh Apandi, Yulianto dan Feni Rosalia (2019) yang menyatakan bahwa gaya kepemimpinan dan motivasi berpengaruh positif dan signifikan terhadap kinerja pegawai pada Tenaga Pendidikan di Biro Umum dan Keuangan Universitas Lampung.

b. Pengaruh Motivasi Kerja Terhadap Kinerja

Berdasarkan hasil pengujian hipotesis secara parsial diketahui bahwa motivasi kerja menjadi pengaruh positif dan signifikan yang dimediasi oleh kepuasan kerja terhadap kinerja pegawai negeri sipil pada Dinas Pekerjaan Umum dan Penataan Ruang Kabupaten Tapanuli Tengah. Pegawai termotivasi untuk bekerja dengan suatu tujuan yaitu suatu harapan kebutuhan karena motivasi pegawai terdorong berbuat lebih baik dari apa yang pernah dibuat sebelumnya maupun yang diraih orang lain yang dapat diukur melalui kebutuhan 
pencapaian (need for achievement), kebutuhan kekuatan (need for power), kebutuhan berhubungan (need for affiliation). Hal ini sesuai dengan pendapat Mc Clelland dalam Mangkunegara (2016:97) motivasi berprestasi adalah daya penggerak yang mendorong semangat pegawai, karena kebutuhan berprestasi mendorong pegawai mengembangkan kreativitas dan mengaktualkan kemampuan, serta energi yang dimilikinya untuk mencapai prestasi yang maksimal. Peneliti terdahulu yang dilakukan Noviani dan Widhiyani (2018) yang menyatakan bahwa motivasi dan pelatihan berpengaruh positif dan signifikan terhadap kinerja karyawan di koperasi pasar Srinadi Klungkung. Jika instansi memberi kesempatan kepada pegawai untuk berprestasi, maka pegawai akan antusias untuk mencapainya. Pegawai akan bergairah untuk melakukan sesuatu lebih baik dan lebih effisien dibandingkan hasil sebelumnya.

c. Pengaruh Pelatihan Terhadap Kinerja

Sesuai dengan hasil pengujian hipotesis secara parsial menunjukkan bahwa pelatihan berpengaruh positif terhadap kinerja pegawai negeri sipil dan Dinas Pekerjaan Umum dan Penataan Ruang Kabupaten Tapanuli Tengah. Berkaitan dengan pengaruh pelatihan terhadap kinerja, maka Dinas Pekerjaan Umum Dan Penataan Ruang Kabupaten Tapanuli Tengah melaksanakan program pembenahan terhadap seluruh sumber daya yang ada pada organisasi, termasuk sumber daya manusia.
Suatu program yang terstruktur tetapi fleksibel serta dirancang untuk jangka panjang untuk upaya menciptakan kemampuan pegawai yang handal memiliki kompetensi serta dapat mengantisipasi perubahan yang terjadi. Suatu upaya membentuk pegawai memiliki kompetensi, Dinas Pekerjaan Umum dan Penataan Ruang Kabupaten Tapanuli Tengah melaksanakannya dengan berbagai jenis pelatihan. Dengan adanya pelatihan yang terencana dengan baik, pegawai akan mampu menyesuaikan dengan dinamika perkembangan ilmu pengetahuan dan teknologi. Berdasarkan penelitian terdahulu yang dilakukan oleh Harahap dan Silvianita (2016) menyatakan bahwa pengaruh pelatihan terhadap kinerja karyawan PT. Pos Indonesia (Persero) Regional V Bandung berpengaruh secara positif. Sesuai dengan hasil penelitian diketahui bahwa variabel motivasi kerja yang paling dominan yang memengaruhi kinerja pegawai negeri sipil (PNS) pada Dinas Pekerjaan Umum dan Penataan Ruang Kabupaten Tapanuli Tengah. Artinya variabel motivasi kerja lebih berperan dalam menentukan kinerja pegawai negeri sipil (PNS) pada Dinas Pekerjaan Umum dan Penataan Ruang Kabupaten Tapanuli Tengah dibandingkan dengan variabel kepemimpinan dan pelatihan dalam instansi.

\section{KESIMPULAN DAN SARAN}

Adapun kesimpulan dari penelitian ini adalah secara parsial kepemimpinan 
berpengaruh positif dan signifikan terhadap kinerja pegawai negeri sipil pada Dinas Pekerjaan Umum dan Penataan Ruang Kabupaten Tapanuli Tengah. Secara parsial motivasi kerja berpengaruh positif dan signifikan terhadap kinerja pegawai negeri sipil pada Dinas Pekerjaan Umum dan Penataan Ruang Kabupaten Tapanuli Tengah. Secara parsial pelatihan berpengaruh positif dan signifikan terhadap kinerja pegawai negeri sipil pada Dinas Pekerjaan Umum dan Penataan Ruang Kabupaten Tapanuli Tengah.

Kepemimpinan, motivasi kerja dan pelatihan secara serempak berpengaruh positif

\section{REFERENSI}

Hasibuan, Malayu S.P., (2013). Manajemen Sumber Daya Manusia. Edisi Revisi. Jakarta : PT Bumi Aksara.

James Kouzes and Barry Posner. (2015) The Leadership Challenge. Sidoarjo : Interaksara.

Kaswan., (2012). Manajemen Sumber Daya Manusia. Yogyakarta : Graha Ilmu.

Mangkunegara, A.A. Anwar Prabu., (2016). Manajemen Sumber Daya Manusia Perusahaan. Bandung : PT. Remaja Rosdakarya.

Moeheriono. ,(2014). Pengukuran Kinerja Berbasis Kompetensi Edisi Ke 4. Yogyakarta : BPFE.

Pullin, Ellen Bolman, Curtis P. Haugvedt. 2013. "Individual Differences in Intrinsic Motivation and The Use of Cooperative Negotiation Tactics". The dan signifikan terhadap kinerja pegawai negeri sipil pada Dinas Pekerjaan Umum dan Penataan Ruang Kabupaten Tapanuli Tengah.

Sedangkan saran dari penelitian ini adalah penelitian selanjutnya diharapkan dapat menjadi referensi dalam menganalisis kinerja sebuah instansi pemerintah, serta menambahkan lagi kajian-kajian yang mendalam dari luar hasil audit BPK untuk mengetahui sejauh mana sebenarnya kinerja organisasi.

Journal of Business \& Industrial Marketing. 15. 446-478.

Priansa dan Juni D. (2014). Perencanaan dan Pengembangan Sumber Daya Manusia. Bandung : Alfabeta

Rivai, Veithzal dan Mulyadi, D., (2012). Kepemimpinan dan Perilaku Organisasi Edisi Tiga. Jakarta : Raja Grafindo Persada.

Rivai, Veithzal dan Sagala J. (2011). Manajemen Sumber Daya Manusia Untuk Perusahaan Dari Teori ke Praktik. Jakarta : Rajawali Press.

Rorimpandey, Lidya., (2013) Gaya kepemimpinan Transformasional, Transaksional, Situasional, Pelayanan dan Autentik Terhadap Kinerja Pegawai Kelurahan di Kecamaatan Bunaken Kota Manado. Fakultas Ekonomi dan Bisnis Jurusan 
Manajemen. Jurnal EMBA. ISSN 2303-1174. Vol.1 No.4:2233-2244.

Setyowati, Subroto., (2018). Pengaruh Pelatihan dan Motivasi Terhadap Kinerja Karyawan : Jurnal Ekonomi dan Kewirausahaan Optimal Vol.12 No.1

Siswanti, Yuni., (2018). Pengaruh Kepemimpinan Terhadap Kinerja Karyawan Dengan Motivasi Sebagai Variabel Moderasi. Tesis Program Studi Magister Manajemen Fakultas Ekonomi Dan Bisnis Universitas Lampung.

Sunyoto, Danang., (2012). Teori, Kuesioner, Dan Analisis Data Sumber Daya Manusia. Yogyakarta : Center For Academic Publishing Service.

Sugiyono., (2013). Metode Penelitian Kuantitatif Kualitatif dan $R \& D$. Bandung : Alfabeta

Sutikno, Sobry. (2014). Pemimpin dan Gaya Kepemimpinan Edisi Pertama. Lombok : Holistica

Sutrisno, Edy. (2013). Manajemen Sumber Daya Manusia, Cetakan Kelima. Yogyakarta : Prenada Media.

Widodo, Suparno E. (2015). Manajemen Pengembangan Sumber Daya Manusia. Yogyakarta : Pustaka Pelajar. Yukl, Gary., (2015). Leadership in Organization, Seventh Edition Kepemimpinan dalam Organisasi, Edisi Ketujuh. Jakarta : Indeks.

Yeh, H., dan D. Hong. 2012. The Mediating Effect of Organizational Commitment on Leadership Type and Job
Performance. The Journal of Human Resource and Adult Learning, Vol.50. p.50-59. 